\title{
Synthesis of glycoconjugate carbonic anhydrase inhibitors by ruthenium- catalysed azide-alkyne 1,3-dipolar cycloaddition
}

Adam J. Salmon, ${ }^{\dagger}$ Michael L. Williams, ${ }^{\dagger}$ Alfonso Maresca, $§$ Claudiu T. Supuran,,${ }^{*}$ and Sally-Ann Poulsen ${ }^{\dagger}, *$

${ }^{\dagger}$ Eskitis Institute for Cell and Molecular Therapies, Griffith University, Nathan, Queensland 4111, Australia, §Polo Scientifico, Laboratorio di Chimica Bioinorganica, Rm. 188, Università degli Studi di Firenze, Via della Lastruccia 3, 50019 Sesto Fiorentino, Florence, Italy.

*Corresponding authors. S.-A.P. Telephone: +61 73735 7825; Fax: +61 73735 7656; e-mail: s.poulsen@griffith.edu.au. C.T.S. Telephone: +; Fax: +; e-mail: claudiu.supuran@unifi.it

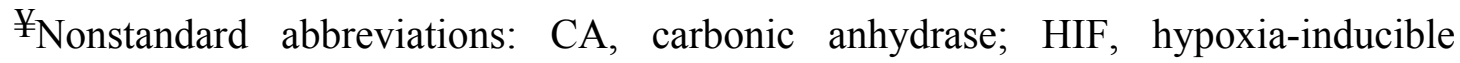
transcription factor; $\mathrm{pH}_{\mathrm{o}}$, extracellular $\mathrm{pH} ; \mathrm{pH}_{\mathrm{i}}$, intracellular $\mathrm{pH}$; $\mathrm{SAR}$, structureactivity relationships; SPR, structure-property relationships; 1,3-DCR, 1,3-dipolar cycloaddition reaction; CuAAC, copper-catalysed azide-alkyne cycloaddition; RuAAC, ruthenium-catalysed azide-alkyne cycloaddition; $\mathrm{Cp}^{*}$, pentamethylcyclopentadienyl; cod, cyclooctadiene; AZA, acetazolamide.

Key words: carbonic anhydrase, click chemistry, triazole, RuAAC, carbohydrate, inhibitor 


\begin{abstract}
Carbonic anhydrase IX (CA IX) is a recently validated target for the development of new cancer therapies. In this paper we describe the synthesis and CA inhibition of a novel series of carbohydrate-based 1,5-disubstituted-1,2,3-triazole benzenesulfonamides. The key step of our synthesis is the regioselective Huisgen's 1,3-dipolar cycloaddition reaction (1,3-DCR) from carbohydrate azide substrates and 4-ethynylbenzenesulfonamide using a ruthenium-catalysed azide-alkyne cycloaddition (RuAAC). Our findings identified a number of triazole inhibitors (compounds 18, 19, 21-23 and 26) that block CA IX activity with inhibition constants less than $10 \mathrm{nM}$. One inhibitor (compound 17) possessed very good selectivity for CA IX over off-target CAs. These CA inhibitors have developmental potential to selectively target cancer cells, leading to cell death.
\end{abstract}


Carbonic anhydrase enzymes (CA, EC 4.2.1.1) catalyse the reversible hydration of carbon dioxide $\left(\mathrm{CO}_{2}\right)$ to generate a bicarbonate anion $\left(\mathrm{HCO}_{3}{ }^{-}\right)$and a proton $\left(\mathrm{H}^{+}\right) .{ }^{1,2}$ Recent advances in our knowledge of the physiological impact of this simple reaction have validated CA IX as a target for cancer therapy intervention. CA IX expression is upregulated in a wide variety of hypoxic tumors, while expression is typically absent in healthy cells (with the exception of cells in the stomach and gastrointestinal tract). ${ }^{3}$, ${ }^{4} \mathrm{CA}$ IX underpins a robust $\mathrm{pH}$-regulating system that allows tumor cells growing in a hypoxic and acidic microenvironment to survive and proliferate. ${ }^{5}$ The topology of CA IX comprises an extracellular catalytic domain, this differs to the ubiquitously expressed, off-target CA II which is a soluble, cytosolic enzyme. ${ }^{2}$ CA IX inhibitor development requires balancing potency, selectivity and physicochemical properties that are needed to be useful in vivo, allowing the inhibitor to find and interact with CA IX to elicit the desired pharmacological response. The tumor-selective expression of CA IX together with the extracellular localisation of its active site enhances the druggability prospects for CA IX as a molecular target for small molecule inhibitors. The role of medicinal chemistry in the CA field is to develop small molecule inhibitors within this framework. The CA active site comprises a tetrahedral $\mathrm{Zn}^{2+}$ cation that plays both a structural and a catalytic role and is the implied target for drug design. Almost all reported small molecule CA inhibitors comprise a zinc binding group $(Z B G)$ and a 'tail' group. ${ }^{2}$ The primary sulfonamide moiety $\left(-\mathrm{SO}_{2} \mathrm{NH}_{2}\right)$ is the foremost example of a ZBG for CA inhibitors. The 'tail' approach for CA inhibitor development was first described by Supuran and co-workers. ${ }^{6}$ Appending tail groups to an $\mathrm{ArSO}_{2} \mathrm{NH}_{2} \mathrm{ZBG}$ has proven effective in enhancing physicochemical properties such as lipophilicity, solubility, permeability, stability and cytotoxicity for a large number of $\mathrm{CA}$ inhibitors. ${ }^{7,8,9} \mathrm{CA}$ inhibitors that incorporate a hydrophilic moiety such as a cationic pyridinium ${ }^{10,11}$ and ' $\mathrm{Cp} * \mathrm{Ru}(\mathrm{II})$ ' salts, ${ }^{12}$ metal-chelating agents, ${ }^{13-15}$ or carbohydrate moieties ${ }^{16-21}$ have been developed. These compounds have limited membrane permeability and so may better target CA IX over CA II. The attachment of the tail moiety to the $\mathrm{Ar}-\mathrm{SO}_{2} \mathrm{NH}_{2}$ CA anchor has been achieved using straightforward chemistry to form covalent links such as esters, amides, imines, ureas and thioureas.

Our research group has demonstrated the versatility of the 1,3-dipolar cycloaddition reaction $(1,3-D C R)$ of organic azides $\left(R-N_{3}\right)$ with alkynes $\left(R^{\prime}-C \equiv C H\right)$, i.e. the Huisgen reaction, ${ }^{22}$ to form 1,2,3-triazole glycoconjugate $\mathrm{CA}$ inhibitors. ${ }^{9}$ Both 
Meldal $^{23}$ and Sharpless ${ }^{24}$ discovered that catalytic $\mathrm{Cu}(\mathrm{I})$ leads to a dramatic rate enhancement (up to $10^{7}$-fold) and synthesis of the 1,4-disubstituted-1,2,3-triazole product. The reaction is now referred to as the copper-catalysed azide-alkyne cycloaddition (CuAAC) and has rapidly become the premier click chemistry reaction. ${ }^{25,26}$ The regioselective synthesis of the other possible product from $(1,3-$ DCR), the 1,5-disubstituted-1,2,3-triazole, has been achieved more recently by catalysis with ruthenium complexes such as $\left[\mathrm{Cp} * \mathrm{RuCl}\left(\mathrm{PPh}_{3}\right)_{2}\right]$ under relatively mild conditions. ${ }^{27}$ The 1,2,3-triazole mimics a peptide bond but is chemically robust in vivo, hence the adoption of this moiety into medicinal chemistry research programs. ${ }^{26}$, ${ }^{28}$ The triazole moiety can either play a passive or active role when incorporated into a pharmacophore. When operating passively the triazole provides a non-labile covalent spacer between discrete $\mathrm{N}-1$ and $\mathrm{C}-4$ or C-5 substituents. Alternatively, when operating in an active capacity the triazole participates through direct interactions with the biological target. ${ }^{26}$ While applications of CuAAC in medicinal chemistry abound, ${ }^{25,28-30}$ to date there remains relatively few applications of RuAAC. ${ }^{31-39}$

Our group has previously developed membrane impermeable carbohydratebased CA inhibitors from azido sugars 2-6 (Figure 1a) and $p$ ethynylbenzenesulfonamide 1 using CuAAC to generate 1,4-disubstituted-1,2,3triazole benzenesulfonamides 7-16, Figure $2 \mathrm{~b} .{ }^{19}$ In another study we reacted organometallic ferrocenyl and ruthenocenyl alkynes with $p$-azidobenzenesulfonamide using both $\mathrm{CuAAC}$ and RuAAC to generate 1,4- and 1,5-disubstitituted 1,2,3-triazole benzenesulfonamide compounds, respectively, to the best of our knowledge the first medicinal chemistry application utilising the regioselective RuAAC, Figure $2 \mathrm{c} .{ }^{39} \mathrm{We}$ found that the differing orientation of the metallocene moiety relative to the benzenesulfonamide moiety impacted on both potency and CA isozyme selectivity. In these compounds the 1,4-disubstituted triazole regioisomer had better CA IX selectivity than the 1,5-disubstituted triazole regioisomer.

Figure 1. intended for color reproduction on the Web and in print

a)
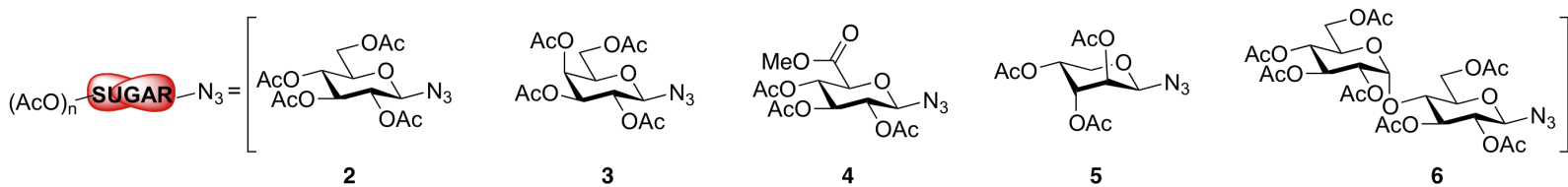

5 
b)

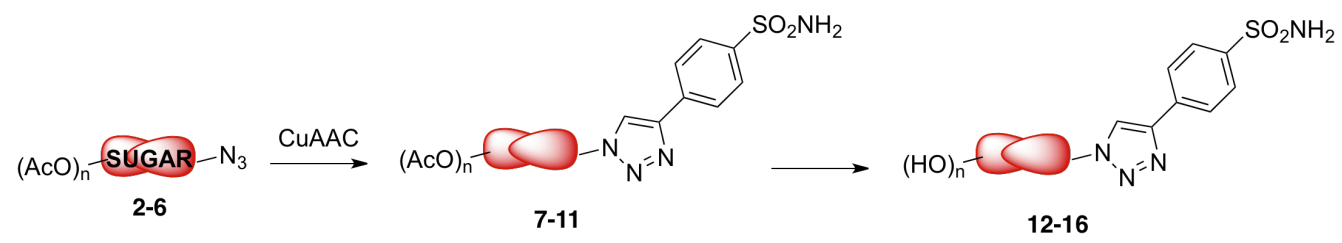

c)

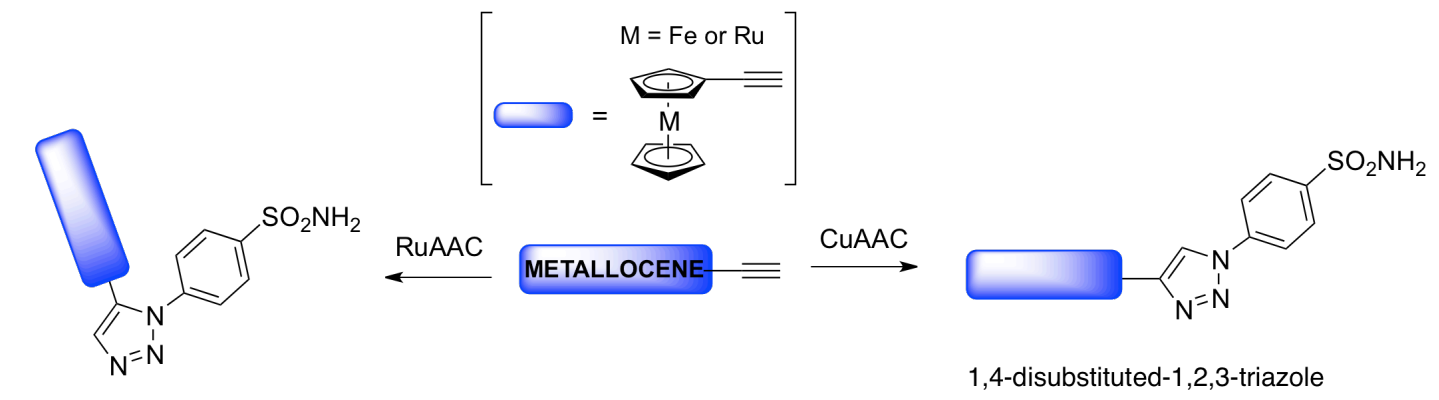

1,5-disubstituted-1,2,3-triazole

In the present study our intention is to build upon SAR generated from carbohydratebased triazole $\mathrm{CA}$ inhibitors prepared with $\mathrm{CuAAC}^{19}$ by applying the 'reverse regioselectivity' RuAAC reaction conditions to generate a corresponding library of 1( $\beta$-D-glycosyl)-5-benzenesulfonamide-1,2,3-triazole compounds 17-26, Figure 2. To commence, a panel of per- $O$-acetyl- $\beta$-D-glycopyranosyl azides (2-6, Figure 1a) were first synthesised from the corresponding $\alpha$-glycosylbromide or $\alpha$-glycosylchloride and $\mathrm{NaN}_{3}$ by phase transfer nucleophilic displacement of the halide. The per- $O$-acetyl- $\beta$-D-glycopyranosyl azide library included derivatives of D-glucose (2), D-galactose (3), D-glucuronic acid methyl ester (4), D-arabinose (5) and D-maltose (6). Optimisation of the RuAAC reaction conditions was performed by studying the synthesis of the 1,5-disubstituted-1,2,3-triazole $\mathbf{1 7}$ from azide $\mathbf{2}$ and p-ethynylbenzenesulfonamide 1. Reaction conditions were adapted from those reported by Zhang and co-workers using $\left[\mathrm{Cp} * \mathrm{RuCl}\left(\mathrm{PPh}_{3}\right)_{2}\right]$ as catalyst. ${ }^{27} \mathrm{We}$ observed that an increase in catalyst loading and/or reaction time results in an improved reaction yield (Table 1, entries 1-3), however yields are low. Decomposition of the catalyst to a tetraazadiene may in part account for the low yields. ${ }^{40}$ In addition triphenylphosphine and triphenylphosphine oxide (formed from oxidation of triphenylphosphine ligands) proved difficult to separate from the target 
triazole compound during purification. Boren and co-workers reported a study of $\left[\mathrm{Cp} * \mathrm{RuCl}\left(\mathrm{PPh}_{3}\right)_{2}\right]$ and $[\mathrm{Cp} * \mathrm{RuCl}(\mathrm{cod})]$ catalysts in the RuAAC synthesis of 1,5-disubstituted-1,2,3-triazoles. ${ }^{40}$ These catalysts share the same mechanism, however the cod (cyclooctadiene) ligand of $[\mathrm{Cp} * \mathrm{RuCl}(\operatorname{cod})]$ is more labile than the triphenylphosphine ligand of $\left[\mathrm{Cp} * \mathrm{RuCl}\left(\mathrm{PPh}_{3}\right)_{2}\right]$, and this resulted in higher reactivity and reaction yields. ${ }^{40} \mathrm{We}$ explored the use of $[\mathrm{Cp} * \mathrm{RuCl}(\mathrm{cod})]$ to synthesise $\mathbf{1 7}$ as an alternate ' $\mathrm{Cp} * \mathrm{RuCl}$ ' catalyst. Our findings were consistent with those reported, a comparison of Table 1, entries 2 and 4 shows the yield improves from $25 \%$ to $42 \%$ when $[\mathrm{Cp} * \mathrm{RuCl}(\mathrm{cod})]$ is used as $\mathrm{RuAAC}$ catalyst in place of $\left[\mathrm{Cp} * \mathrm{RuCl}\left(\mathrm{PPh}_{3}\right)_{2}\right]$. The cod ligand impurity was separated from the target triazole product in a straightforward manner, in contrast to the difficult removal of triphenylphosphine and triphenylphosphine oxide by-products when $\left[\mathrm{Cp} * \mathrm{RuCl}\left(\mathrm{PPh}_{3}\right)_{2}\right]$ was used as catalyst.

\section{Figure 2.}

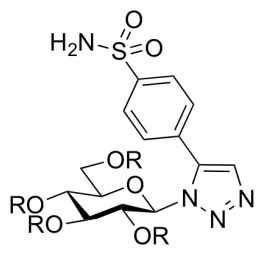

$17 \mathrm{R}=\mathrm{Ac}$
$22 \mathrm{R}=\mathrm{H}$

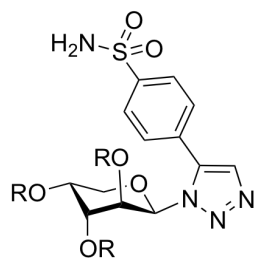

$20 \mathrm{R}=\mathrm{Ac}$
$25 \mathrm{R}=\mathrm{H}$

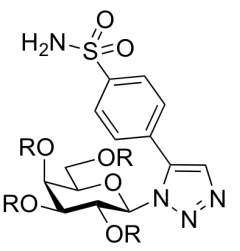

$18 R=A c$
$23 R=H$

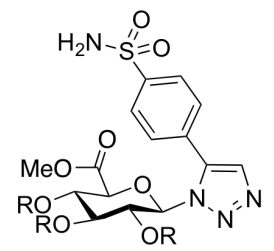

$19 \mathrm{R}=\mathrm{Ac}$ $24 \mathrm{R}=\mathrm{H}$

Table 1.

\begin{tabular}{|c|c|c|c|c|}
\hline Entry & Catalyst $^{a}$ & $\begin{array}{c}\text { Catalyst loading } \\
\text { (mol \%) }\end{array}$ & $\begin{array}{c}\text { Reaction time } \\
\text { (h) }\end{array}$ & $\begin{array}{c}\text { Yield } \\
\text { (\%) }\end{array}$ \\
\hline $\mathbf{1}$ & {$\left[\mathrm{Cp} * \mathrm{RuCl}\left(\mathrm{PPh}_{3}\right)_{2}\right]$} & 5 & 4.5 & 20 \\
\hline $\mathbf{2}$ & {$\left[\mathrm{Cp} * \mathrm{RuCl}\left(\mathrm{PPh}_{3}\right)_{2}\right]$} & 5 & 18 & 25 \\
\hline $\mathbf{3}$ & {$\left[\mathrm{Cp} * \mathrm{RuCl}\left(\mathrm{PPh}_{3}\right)_{2}\right]$} & 20 & 18 & 34 \\
\hline $\mathbf{4}$ & {$[\mathrm{Cp} * \mathrm{RuCl}(\mathrm{cod})]$} & 5 & 18 & 42 \\
\hline
\end{tabular}


${ }^{a}$ Reagents and Conditions: azide $2(0.2 \mathrm{M})$, alkyne 6 (1 equiv.), ' $\mathrm{Cp} * \mathrm{RuCl}$ ' catalyst, toluene, $\mathrm{N}_{2}, 100^{\circ} \mathrm{C}$.

The regioselective synthesis of 1,5-disubstituted-1,2,3-triazoles 17-21 was achieved by RuAAC between azides 2-6 and $p$-ethynylbenzenesulfonamide $\mathbf{1}$ using [Cp*RuCl(cod)], Scheme 1. Compounds 17-21 were prepared in moderate yield (21$63 \%$ ). Deacetylation of the sugar moieties of glycoconjugate compounds was conducted using the standard Zemplén conditions of $0.05 \mathrm{M}$ sodium methoxide in methanol, ${ }^{41}$ to afford compounds 22, 23, 25 and 26 in good yields $(65-99 \%){ }^{41}$ The characteristic singlet resonance in the ${ }^{1} \mathrm{H}$ NMR spectrum attributable to the $\mathrm{H}-5$ proton of the triazole moiety is evidence for the formation of the desired regioselectivity. The H-4 proton of the 1,4-disubstituted triazoles resonates at $\delta 9.87$ and $8.68 \mathrm{ppm},{ }^{19}$ while the $\mathrm{H}-5$ proton of $\mathbf{1 7 - 2 6}$ resonates at $\delta 8.12$ and $8.04 \mathrm{ppm}$, around 1 ppm upfield of the 1,4-disubstituted regioisomer. ${ }^{13} \mathrm{C}$ NMR spectroscopy revealed the resonance expected for the triazole $\mathrm{CH}$ carbon. For the 1,4-disubstituted triazoles this carbon resonates at $\delta 122.7-122.4,{ }^{19}$ while for the 1,5 -disubstituted triazole this carbon resonates at $\delta 134.9-133.5$. These chemical shifts are fully consistent with those reported previously for 1,4- and 1,5-disubstituted 1,2,3triazoles. ${ }^{42,43}$ Deprotection of the glucuronic acid methyl ester analogue $\mathbf{1 9}$ to give $\mathbf{2 4}$ resulted in saponification of the methyl ester, this was an oily residue that could not be purified to the purity level desired for use in downstream enzyme inhibition studies.

Scheme 1. intended for color reproduction on the Web and in print
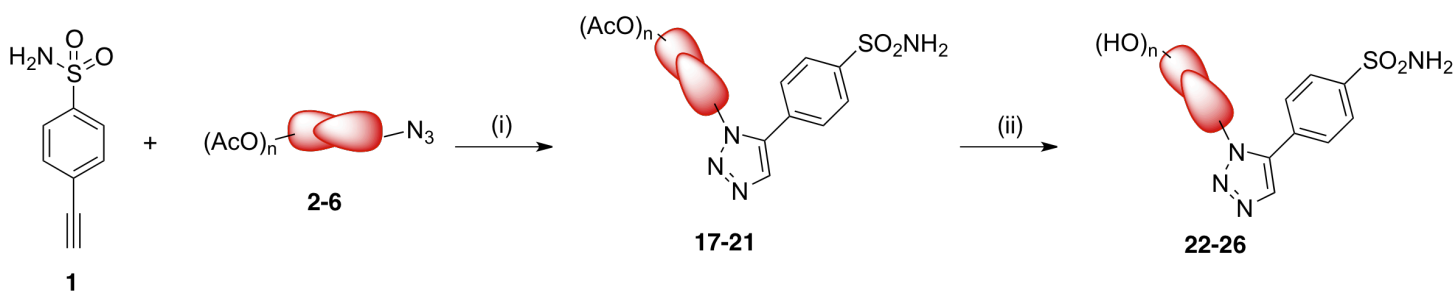

${ }^{a}$ Reagents and Conditions: (i) azide 2-6 (0.2 M), alkyne 6 (1.0 - 1.5 equiv.), 5 mol\% [Cp*RuCl(cod)], toluene, $\mathrm{N}_{2}, 100{ }^{\circ} \mathrm{C}, 18 \mathrm{~h},(21-63 \%)$; (ii) $\mathrm{NaOMe}$ in $\mathrm{MeOH}(0.05$ $\mathrm{M}, \mathrm{pH} 12)$, anhydrous $\mathrm{MeOH}, 0{ }^{\circ} \mathrm{C}-\mathrm{rt}, 30 \mathrm{~min}-16 \mathrm{~h},(65-99 \%)$.

The enzyme inhibition data for 1, 1,4-disubstituted-1,2,3-triazole benzenesulfonamide 
glycoconjugates 7-11 and their deprotected analogues 12-16, ${ }^{19}$ and the 1,5-disubstituted-1,2,3-triazole benzenesulfonamide glycoconjugates of this study 17-26 is presented in Table 2. Data is acquired at the off-target CA I and II, and tumor-associated CA IX. Data for acetazolamide (AZA), a clinically used CA inhibitor, is also included.

Table 2. intended for color reproduction on the Web and in print

\begin{tabular}{|c|c|c|c|c|c|}
\hline \multirow{3}{*}{ Compound } & \multicolumn{2}{|c|}{$\begin{array}{c}\text { 1,4-disubstituted triazoles } \\
7-16\end{array}$} & \multicolumn{2}{|c|}{$\begin{array}{c}\text { 1,5-disubstituted triazoles } \\
17-26\end{array}$} & \\
\hline & \multicolumn{3}{|c|}{$K_{\mathrm{i}} \mathrm{s}(\mathrm{nM})^{a, b}$} & \multicolumn{2}{|c|}{$K_{\mathrm{i}}$ Selectivity Ratios ${ }^{c}$} \\
\hline & CA I & CA II & CA IX & $\begin{array}{c}\text { CA I/ } \\
\text { CA IX }\end{array}$ & $\begin{array}{l}\text { CA II/ } \\
\text { CA IX }\end{array}$ \\
\hline AZA & 250 & 12 & 25 & 0.48 & 0.48 \\
\hline 1 & 1080 & 5.1 & 8.1 & 133.3 & 0.63 \\
\hline 7 & 4400 & 9.1 & 120 & 36.7 & 0.08 \\
\hline 8 & 4300 & 8.7 & 110 & 39.1 & 0.08 \\
\hline 9 & 48 & 13 & 9.9 & 4.84 & 1.3 \\
\hline 10 & 10.5 & 8.2 & 134 & 0.09 & 0.06 \\
\hline 11 & 2500 & 235 & 120 & 20.8 & 1.96 \\
\hline 12 & 9.4 & 380 & 89 & 0.11 & 4.3 \\
\hline 13 & 9.3 & 8.8 & 120 & 0.08 & 0.07 \\
\hline 14 & 560 & 13 & 8.4 & 50.8 & 1.6 \\
\hline 15 & 2.5 & 2.3 & 28 & 0.09 & 0.08 \\
\hline 16 & 5000 & 432 & 130 & 38.5 & 3.32 \\
\hline 17 & 1360 & 163 & 32.6 & 42.7 & 5 \\
\hline 18 & 71 & 2.4 & 7.3 & 9.7 & 0.33 \\
\hline 19 & 3.5 & 3.1 & 7.7 & 0.45 & 0.40 \\
\hline
\end{tabular}


${ }^{a}$ Errors in the range of $\pm 5 \%$ of the reported value, from three determinations. ${ }^{c}$ Obtained using a stopped flow assay that monitors the physiological reaction (CA catalysed hydration of $\mathrm{CO}_{2} .{ }^{c}$ The $K_{\mathrm{i}}$ ratios are indicative of isozyme selectivity for CA IX.

The parent alkyne 1, lacking a carbohydrate tail, displays no selectivity for CA IX $\left(K_{\mathrm{i}}\right.$ $8.1 \mathrm{nM})$ with respect to CA II $\left(K_{\mathrm{i}} 5.1 \mathrm{nM}\right)$ but is 133 -fold stronger inhibitor of CA IX than CA I $\left(K_{\mathrm{i}} 1080 \mathrm{nM}\right)$. At CA I the 1,4-disubstituted triazoles displayed a range of inhibition constants $\left(K_{\mathrm{i}} \mathrm{s} 2.5-5000 \mathrm{nM}\right)$, similarly the 1,5-disubstituted triazoles inhibited CA I over a large range $\left(K_{\mathrm{i}} \mathrm{s} 3.5-4390 \mathrm{nM}\right)$. Most of the 1,5-disubstituted triazoles were significantly more potent than the parent alkyne $\mathbf{1}\left(K_{\mathrm{i}}=1080 \mathrm{nM}\right)$ with $K_{\mathrm{i}} \mathrm{s} 3.5-83 \mathrm{nM}$, there are only two exceptions, the per- $O$-acetyl arabinosyl (20: $K_{\mathrm{i}}$ $4390 \mathrm{nM})$ and glucosyl (17: $\left.K_{\mathrm{i}} 1360 \mathrm{nM}\right)$ derivatives. At CA II, most triazoles were potent inhibitors, many with $K_{\mathrm{i}} \mathrm{s}$ below $10 \mathrm{nM}$, and selectivity for CA II over CA I, similarly to the parent alkyne 1 ( $K_{\mathrm{i}} 5.1 \mathrm{nM}, 211$-fold selective for CA II over CA I). The most noteworthy selectivity compared to CA I was with the 1,5-disubstituted per$O$-acetyl arabinosyl triazole derivative 20 (CA II $K_{\mathrm{i}}=2.9 \mathrm{nM}$ ) which was 1514 -fold selective for CA II compared to CA I. This differs to the corresponding 1,4disubstituted per- $O$-acetyl arabinosyl triazole derivative $\mathbf{1 0}$ which had no selectivity $\left(\right.$ CA I $K_{\mathrm{i}}=10.5 \mathrm{nM}$ and CA II $\left.K_{\mathrm{i}}=8.2 \mathrm{nM}\right)$. At CA IX triazoles displayed a range of inhibition constants $\left(K_{\mathrm{i}} \mathrm{s} 7.0-134 \mathrm{nM}\right)$ compared to the parent alkyne $\mathbf{1}\left(K_{\mathrm{i}} 8.1 \mathrm{nM}\right)$ and with activity similar to CA II. The 1,5-disubstituted triazoles had good CA IX inhibition $\left(K_{\mathrm{i}} \mathrm{s} 7.0-68.3 \mathrm{nM}\right)$, nearly all were better CA IX inhibitors than their 1,4disubstituted counterparts, for example the 1,4- per- $O$-acetyl galactosyl derivative 8 $\left(K_{\mathrm{i}} 110 \mathrm{nM}\right)$ is 15 -fold less active than the corresponding 1,5-galactose derivative 18 $\left(K_{\mathrm{i}} 7.3 \mathrm{nM}\right)$. The per- $O$-acetyl glucosyl analogue $17\left(\mathrm{CA}\right.$ IX $\left.K_{\mathrm{i}}=32.6 \mathrm{nM}\right)$ was the best triazole (1,4- or 1,5-disubstituted) with regard to selectivity for CA IX over offtarget CA I and II, it was 42-fold and 5-fold selective, respectively. This selectivity is 
opposite to that observed with the hydrophobic metallocene tail moieties. ${ }^{39}$ In these compounds the 1,4-disubstituted triazole regioisomer had better CA IX selectivity than the 1,5-disubstituted triazole regioisomer. ${ }^{39}$ As the CA active site encompasses two distinct regions to which the CA inhibitor tail can potentially interact, one lined by hydrophobic amino acids (consisting of $\mathrm{Phe}_{130}, \mathrm{Val}_{134}, \mathrm{Leu}_{203}$ and $\mathrm{Pro}_{201}$ ) and the other located directly opposite and lined by hydrophilic amino acids (primarily $\mathrm{Asn}_{62}$, $\operatorname{Asn}_{67}$ and $\left.\mathrm{Gln}_{92}\right){ }^{2}$ it is logical that hydrophobic versus hydrophilic tail groups may lead to differential isozyme selectivity.

In summary the new compounds of this study comprise a sugar moiety tethered to an aromatic sulfonamide CA pharmacophore through an intervening triazole ring. Compounds 22, 23, 25 and 26 each contain a free sugar moiety and so provide a selection of likely membrane impermeable small molecule CA inhibitors with selectivity for the extracellular active site CA IX over other (intracellular) CA isozymes. The key step of our synthesis is the regioselective Huisgen's 1,3-DCR using $\mathrm{RuAAC}$ with $\left[\mathrm{Cp}^{*} \mathrm{RuCl}(\mathrm{cod})\right]$ as catalyst. Our findings identified a number of 1,5-disubstituted triazole inhibitors (compounds 18, 19, 21-23 and 26) that block CA IX with inhibition constants less than $10 \mathrm{nM}$. One inhibitor (compound 17) possessed very good selectivity for CA IX over off-target CAs. Our results have demonstrated that subtle structural differences in the sugar tail can discriminate the $\mathrm{CA}$ isozyme active site topology to influence enzyme inhibition characteristics. A comparison of the CA IX inhibition of the new 1,5-disubstituted triazoles $\left(K_{\mathrm{i}} \mathrm{s} 7.0-68.3 \mathrm{nM}\right)$ with their 1,4-disubstituted counterparts showed that nearly all were better CA IX inhibitors, a significant step towards further building SAR with carbohydrate-based CA inhibitors. The enzyme inhibition attributes of these compounds are an important result for potential future biological studies or therapeutic applications of carbohydrate-based primary sulfonamide compounds.

Supplementary Data. Supplementary data comprises synthetic procedures; compound characterisation data and the CA assay procedure for new compounds 1726.

\section{Acknowledgements.}


This research was financed in part by the Australian Research Council (Grant number DP0877554 to S.-A.P), Australian Government (Student Scholarships to A.J.S.) and by a grant of the $7^{\text {th }}$ FP of EU (Metoxia project). 


\section{Figure/Scheme/Table Captions}

Figure 1. a) Glycosyl azide building blocks 2-6. b) Glycoconjugate 1,4-disubstituted1,2,3-triazole benzenesulfonamides 7-16 synthesised by CuAAC. c) Organometallic 1,4- and 1,5-disubstitituted 1,2,3-triazoles benzenesulfonamide compounds synthesised by CuAAC and RuAAC, respectively. (intended for color reproduction on the Web and in print)

Figure 2. Target carbohydrate-based 1,5-disubstituted-1,2,3-triazole benzenesulfonamides.

Table 1. Reaction optimisation for RuAAC from azide 2 and alkyne 6 to give 1,5disubstituted-1,2,3-triazole 17.

Scheme 1. Synthesis of target 1,5-disubstituted-1,2,3-triazoles 17-26. (intended for color reproduction on the Web and in print)

Table 2. Inhibition and isozyme selectivity ratio data of CA isozymes I, II, and IX with triazoles 7-26, compound 1, and the established drug and CA inhibitor, AZA. (intended for color reproduction on the Web and in print) 


\section{References.}

1. Krishnamurthy, V. M.; Kaufman, G. K.; Urbach, A. R.; Gitlin, I.; Gudiksen,

K. L.; Weibel, D. B.; Whitesides, G. M. Chem. Rev. 2008, 108, 946.

2. Supuran, C. T. Nat. Rev. Drug Discov. 2008, 7, 168.

3. Potter, C. P. S.; Harris, A. L. Br. J. Cancer 2003, 89, 2.

4. Wykoff, C. C.; Beasley, N. J.; Watson, P. H.; Turner, K. J.; Pastorek, J.; Sibtain, A.; Wilson, G. D.; Turley, H.; Talks, K. L.; Maxwell, P. H.; Pugh, C. W.; Ratcliffe, P. J.; Harris, A. L. Cancer Res. 2000, 60, 7075.

5. Chiche, J.; Ilc, K.; Laferriere, J.; Trottier, E.; Dayan, F.; Mazure, N. M.; Brahimi-Horn, M. C.; Pouyssegur, J. Cancer Res. 2009, 69, 358.

6. Scozzafava, A.; Menabuoni, L.; Mincione, F.; Briganti, F.; Mincione, G.; Supuran, C. T. J. Med. Chem. 1999, 42, 2641.

7. Supuran, C.; Casini, A.; Scozzafava, A. In Carbonic anhydrase: Its inhibitors and activators; Supuran, C. T., Scozzafava, A., Conway, J., Eds.; CRC Press LLC: Florida, 2004.

8. Winum, J.-Y.; Poulsen, S.-A.; Supuran, C. T. Med. Res. Rev. 2009, 29, 419.

9. Lopez, M.; Salmon, A. J.; Supuran, C. T.; Poulsen, S.-A. Curr. Pharm. Des. 2010, 16, 3277.

10. Pastorekova, S.; Casini, A.; Scozzafava, A.; Vullo, D.; Pastorek, J.; Supuran, C. T. Bioorg. Med. Chem. Lett. 2004, 14, 869.

11. Scozzafava, A.; Briganti, F.; Ilies, M. A.; Supuran, C. T. J. Med. Chem. 2000, $43,292$.

12. Loughrey, B. T.; Williams, M. L.; Healy, P. C.; Innocenti, A.; Vullo, D.; Supuran, C. T.; Parsons, P. G.; Poulsen, S. A. J. Biol. Inorg. Chem. 2009, 14, 935.

13. Rami, M.; Cecchi, A.; Montero, J.-L.; Innocenti, A.; Vullo, D.; Scozzafava, A.; Winum, J.-Y.; Supuran, C. T. ChemMedChem 2008, 3, 1780.

14. Rami, M.; Winum, J.-Y.; Innocenti, A.; Montero, J.-L.; Scozzafava, A.; Supuran, C. T. Bioorg. Med. Chem. Lett. 2008, 18, 836.

15. Scozzafava, A.; Menabuoni, L.; Mincione, F.; Supuran, C. T. J. Med. Chem. 2002, 45, 1466.

16. Wilkinson, B. L.; Bornaghi, L. F.; Houston, T. A.; Innocente, A.; Supuran, C. T.; Poulsen, S.-A. J. Med. Chem. 2006, 49, 6539. 
17. Wilkinson, B. L.; Bornaghi, L. F.; Houston, T. A.; Innocenti, A.; Vullo, D.; Supuran, C. T.; Poulsen, S.-A. J. Med. Chem. 2007, 50, 1651.

18. Wilkinson, B. L.; Bornaghi, L. F.; Houston, T. A.; Innocenti, A.; Vullo, D.; Supuran, C. T.; Poulsen, S.-A. Bioorg. Med. Chem. Lett. 2007, 17, 987.

19. Wilkinson, B. L.; Innocenti, A.; Vullo, D.; Supuran, C. T.; Poulsen, S.-A. J. Med. Chem. 2008, 51, 1945.

20. Lopez, M.; Bornaghi, L. F.; Innocenti, A.; Vullo, D.; Charman, S. A.; Supuran, C. T.; Poulsen, S.-A. J. Med. Chem. 2010, 53, 2913.

21. Singer, M.; Lopez, M.; Bornaghi, L. F.; Innocenti, A.; Vullo, D.; Supuran, C. T.; Poulsen, S.-A. Bioorg. Med. Chem. Lett. 2009, 19, 2273.

22. Huisgen, R.; Szeimies, G.; Moebius, L. Chem. Ber. 1967, 100, 2494.

23. Tornoe, C. W.; Christensen, C.; Meldal, M. J. Org. Chem. 2002, 67, 3057.

24. Rostovtsev, V.; Green, L. G.; Fokin, V.; Sharpless, K. Angew. Chem. Int. Ed. 2002, 41, 2596.

25. Moses, J. E.; Moorhouse, A. D. Chem. Soc. Rev. 2007, 36, 1249.

26. Tron, G.; Pirali, T.; Billington, R.; Canonico, P.; Sorba, G.; Genazzani, A. Med. Res. Rev. 2008, 28, 278.

27. Zhang, L.; Chen, X.; Xue, P.; Sun, H. H.; Williams, I. D.; Sharpless, K. B.; Fokin, V. V.; Jia, G. J. Am. Chem. Soc. 2005, 127, 15998.

28. Meldal, M.; Tornoe, C. W. Chem. Rev. 2008, 108, 2952.

29. Kolb, H. C.; Sharpless, K. B. Drug Disc. Today 2003, 8, 1128.

30. Sharpless, K. B.; Manetsch, R. Expert Opin. Drug Discovery 2006, 1, 525.

31. Tam, A.; Arnold, U.; Soellner, M. B.; Raines, R. T. J. Am. Chem. Soc. 2007, $129,12670$.

32. Diaz, L.; Bujons, J.; Casas, J.; Llebaria, A.; Delgado, A. J. Med. Chem. 2010, 53,5248 .

33. Pagliai, F.; Pirali, T.; Del Grosso, E.; Di Brisco, R.; Tron, G. C.; Sorba, G.; Genazzani, A. A. J. Med. Chem. 2005, 49, 467.

34. Shen, J.; Woodward, R.; Kedenburg, J. P.; Liu, X.; Chen, M.; Fang, L.; Sun, D.; Wang, P. G. J. Med. Chem. 2008, 51, 7417.

35. Colombano, G.; Travelli, C.; Galli, U.; Caldarelli, A.; Chini, M. G.; Canonico, P. L.; Sorba, G.; Bifulco, G.; Tron, G. C.; Genazzani, A. A. J. Med. Chem. 2009, 53, 616. 
36. Wuest, F.; Tang, X.; Kniess, T.; Pietzsch, J.; Suresh, M. Bioorg. Med. Chem. 2009, 17, 1146.

37. Jiang, Y.; Hansen, T. V. Bioorg. Med. Chem. Lett. 2011, 21, 1626.

38. Pradere, U.; Roy, V.; McBrayer, T. R.; Schinazi, R. F.; Agrofoglio, L. A. Tetrahedron 2008, 64, 9044.

39. Salmon, A. J.; Williams, M. L.; Innocenti, A.; Vullo, D.; Supuran, C. T.; Poulsen, S.-A. Bioorg. Med. Chem. Lett. 2007, 17, 5032.

40. Boren, B. C.; Narayan, S.; Rasmussen, L. K.; Zhang, L.; Zhao, H.; Lin, Z.; Jia, G.; Fokin, V. V. J. Am. Chem. Soc. 2008, 130, 8923.

41. Zemplén, G. Ber. Deutsch. Chem. Ges. 1926, 59, 1254.

42. Crandall, J. K.; Crawley, L. C.; Komin, J. B. J. Org. Chem. 1975, 40, 2045.

43. Holzer, W. Tetrahedron 1991, 47, 9783. 